\title{
Pembuatan Alat Bantu Ajar Biologi Ikan Timpakul dan Ekosistem Mangrove bagi Anak Sekolah Dasar di Desa Pagatan Besar Kabupaten Tanah Laut
}

\author{
Anang Kadarsah ${ }^{* 1}$, Nurul Huda ${ }^{2}$, Krisdianto $^{3}$, Hidayaturrahmah $^{4}$, Ika Oksi Susilawati ${ }^{5}$ \\ ${ }^{* 1,3,4,5}$ Program Studi Biologi FMIPA Universitas Lambung Mangkurat \\ ${ }^{2}$ Program Studi Matematika FMIPA Universitas Lambung Mangkurat \\ Jl. A. Yani Km. 35,8 Banjarbaru Kalimantan Selatan 70714 Telp.0511-4773112 \\ Email korespondensi : anangkadarsah@ulm.ac.id
}

\begin{abstract}
The activities of the knowledge and technology sciences for the community are intended to (1) describe the economic value of timpakul fish and mangrove ecosystem in Pagatan Besar Village. (2) to introduce aids and learning media with biological themes of mangrove fish and mangrove ecosystems for school age children at SDN Pegatan Besar, and (3) to train the development of cognitive, affective, and psychomotor aspects of school children in SDN Pegatan Besar through theme approach biological based fish timpakul and mangrove ecosystems. In this activity, exposure to biological fish biology and the prospect of utilization. Next is a presentation on the mangrove ecosystem and its prospect of utilization at Pagatan Besar Beach. The third activity is the training of biology teaching materials and mangrove ecosystems for school-age children at SDN Pegatan Besar. Fourth assessment of the product from the training of biology materials and mangrove ecosystem training for elementary school children at SDN Pegatan Besar. The closing of this activity is the demonstration of training materials for timpakul biological materials and mangrove ecosystems in Pagatan Besar Village. The results of the devotion show a positive values where the participants followed this activity enthusiastically. Similarly, questionnaire filling where most of them know about the ecosystem of mangrove and timpakul $(97 \%)$. Only a small percentage of respondents $(2.5 \%)$ answered that for the conservation of mangroves and timpakul we must maintain and preserve the mangrove and have to throw garbage into the bin. Most respond only to one choice, for example not throwing out random garbage (17.5\%) and planting 5\% trees.
\end{abstract}

Keywords: teaching aids, timpakul fish, mangrove ecosystems

\begin{abstract}
Abstrak
Kegiatan pengabdian ilmu pengetahuna dan teknologi bagi masyarakat ini bertujuan (1) mendeskripsikan nilai ekonomi ikan timpakul dan ekosistem mangrove di Desa Pagatan Besar. (2) mengenalkan alat bantu dan media belajar dengan tema biologi ikan timpakul dan ekosistem mangrove bagi anak-anak usia sekolah di SDN Pegatan Besar, dan (3) melatih pengembangan aspek kognitif, afektif, dan psikomotor anak sekolah di SDN Pegatan Besar melalui pendekatan
\end{abstract}


tema berbasis biologi ikan timpakul dan ekosistem mangrove. Dalam kegiatan ini dilakukan pemaparan mengenai biologi ikan timpakul dan prospek pemanfaatannya. Selanjutnya adalah pemaparan mengenai ekosistem mangrove dan prospek pemanfaatannya di Pantai Pagatan Besar. Kegiatan ketiga berupa pelatihan pembuatan bahan ajar biologi timpakul dan ekosistem mangrove bagi anak-anak usia sekolah di SDN Pegatan Besar. Keempat penilaian produk dari hasil pelatihan bahan ajar biologi timpakul dan ekosistem mangrove bagi anakanak usia sekolah di SDN Pegatan Besar. Penutup kegiatan ini adalah pemajangan produk pelatihan bahan ajar biologi timpakul dan ekosistem mangrove di halaman SDN Pegatan Besar. Hasil pengabdian menunjukan nilai positif dimana peserta mengikuti kegiatan ini dengan antusias. Demikian pula dengan pengisian kuesioner dimana sebagian besar menyatakan tahu tentang ekosistem mangrove dan timpakul $(97 \%)$. Hanya sebagian kecil responden yang menjawab (2,5\%) dengan lengkap bahwa untuk pelestarian mangrove dan timpakul kita harus menjaga dan melestarikan mangrove dan harus membuang sampah ke tempat sampah. Sebagian besar menjawab hanya satu pilihan saja, misalnya tidak membuang sampah sembarangan $(17,5 \%)$ dan menanam pohon sebanyak $5 \%$.

Kata kunci : alat bantu ajar, ikan timpakul, ekosistem mangrove

\section{PENDAHULUAN}

Pagatan Besar termasuk salahsatu desa yang berada di Kecamatan Takisung, Kabupaten Tanah Laut serta masuk ke dalam konservasi perairan daerah Suaka Margasatwa (SM) Pelaihari Tanah Laut (Hafizianor, 2009). Saat ini Desa Pagatan Besar memiliki potensi alam berupa pesisir pantai yang indah dan sangat panjang dibanding pesisir obyek wisata alam lainnya sedang dikembangkan potensi lahan mangrove menjadi obyek wisata. Meski tumbuhan mangrove di Desa Pagatan Besar belum rimbun seperti kondisi ekowisata mangrove pantai Indah Kapuk di DKI Jakarta atau ekowisata mangrove di Kabupaten Badung, Provinsi Bali, namun sudah tak terhitung warga berkunjung atau sekadar swafoto bersama teman dekat atau rombongan. Bagi yang punya hobi memancing, ada dua jembatan yang dibikin hingga ke bibir pantai. Di situ setiap sore hingga malam hari ada saja yang memancing ikan. Jika ingin salat atau berteduh menikmati hidangan di dalam kawasan hutan mangrove, tersedia dua gazebo untuk berkumpul setelah berjalan (Ahmad, 2017).

Meskipun kawasan hutan mangrove di desa ini telah dijadikan hutan konservasi dalam program pengembangan kawasan pesisir tangguh (PKPT), namun dalam praktek pengelolaan dan konservasi hutan mangrove masih banyak mengalami tantangan dan hambatan. Dalam hal ini tantangan terbesar justru berasal dari sebagian masyarakat desa dari kalangan orang tua yang enggan memberikan perhatian terhadap kelestarian ekosistem mangrove di Pantai Pagatan Besar beserta organisme eksotik yang tinggal bersamanya yakni ikan Timpakul (Mudskipper, Famili Gobiidae)

Berbeda halnya dengan generasi tua yang cenderung abai, kalangan generasi muda khususnya anak-anak usia sekolah sangat antusias dengan dengan kehadiran ikan timpakul dan keberadaan ekosistem mangrove di pesisir pantai (Anonim. 2017). Hal ini 
Anang Kadarsah, Nurul Huda, Krisdianto

dapat dilihat dari hasil perhitungan sensus penduduk tahun 2016 bahwa sekitar 27,38\% adalah penduduk yang berumur di bawah sepuluh tahun kemudian $45,13 \%$ adalah penduduk berusia di bawah dua puluh tahun dan sekitar $62,11 \%$ adalah penduduk berusia di bawah tiga puluh tahun (Kadarsah dan Krisdianto, 2017).

Tingginya potensi usia muda tentu akan berpengaruh terhadap pandangan mengenai timpakul dan ekosistem mangrove. Dalam hal ini banyaknya kunjungan anakanak sekolah khususnya pada hari-hari menjelang libur panjang untuk mengetahui dan menelusuri ekosistem mangrove yang membentang sejauh $2 \mathrm{~km}$ di pesisir pantai Pagatan Besar di satu sisi menjadi hal yang patut dibanggakan namun di sisi lain memprihatinkan karena umumnya mereka tidak memperhatikan kebersihan lingkungan dan tidak memerdulikan kelestarian ekosistem mangrove. Dengan memperhatikan kondisi tersebut di atas dan atas saran dari Kepala Desa Pagatan Besar, maka penting dan perlu dilakukan untuk membangkitkan kesadaran konservasi ikan timpakul dan ekosistem mangrove adalah dengan memperkenalkan keberadaan ikan timpakul dan ekosistem mangrove, sehingga merasa memiliki kedekatan dengannya.

Dan untuk mencapai hal tersebut, maka media pembelajaran yang berkualitas adalah poin penting yang perlu dipenuhi sebagai sarana penghubung pesan yang disampaikan dan menilai kompetensi yang harus dicapai oleh siswa dalam kegiatan belajar. Nielsen (2008) yang mengemukakan bahwa pembelajaran yang dilakukan pada anak usia dini dapat menambah pengetahuan dan kualitas pengalaman mereka. Sedangkan menurut Sujiono (2007) anak hendaknya diberi kesempatan luas dalam pembelajaran untuk mengembangkan potensinya. Selanjutnya anak diberi kesempatan untuk mengintegrasikan pengetahuan deklaratif yang telah dipelajari dengan pengetahuan prosedural untuk melakukan tugas-tugas dan memecahkan masalah.

Dalam rangka meningkatkan khazanah pengetahuan ikan timpakul dan pengembangan potensi wisata ekosistem mangrove di Pantai Pagatan Besar, Kabupaten Tanah Laut, maka pengembangan alat bantu ajar berbasis biologi ikan timpakul dan aplikasi konservasi ekosistem mangrove menjadi salah satu rencana strategis yang penting dikerjakan. Tim pengusul pengabdian Program Studi Biologi Fakultas Matematika dan Ilmu Pengetahuan Alam Universitas Lambung Mangkurat terpanggil melakukan kegiatan yang mendukung tujuan konservasi mangrove melalui pelatihan pembuatan alat ajar di SDN Pegatan Besar, Desa Pagatan Besar, Kecamatan Takisung, Kabupaten Tanah Laut.

Dalam hal ini, perumusan masalah yang diajukan dalam kegiatan ini adalah : (1) bagaimana deskripsi nilai ekonomi ikan timpakul dan ekosistem mangrove yang berada di Desa Pagatan Besar. (2) bagaimana bentuk alat bantu belajar bertema biologi ikan timpakul dan ekosistem mangrove yang cocok bagi anak-anak usia sekolah di SDN Pegatan Besar, Desa Pagatan Besar, Kecamatan Takisung, dan (3) bagaimana kemajuan aspek kognitif, afektif, dan psikomotor anak sekolah di SDN Pegatan Besar Kecamatan Takisung setelah pelatihan pembuatan alat ajar berbasis biologi ikan timpakul dan ekosistem mangrove. 


\section{METODE}

\section{Lokasi dan Khalayak Sasaran}

Lokasi kegiatan pengabdian ini adalah di Wilayah Desa Pagatan Besar Kabupaten Tanah Laut. (Gambar 1.) Lokasi pengabdian dapat ditempuh selama 1 jam 35 menit dari Kampus FMIPA Universitas Lambung Mangkurat di Banjarbaru dengan perkiraan jarak antara keduanya adalah sekitar 69,5 kilometer. Batas-batas desa Pagatan Besar meliputi : (1) sebelah utara adalah Desa Tabanio Kecamatan Takisung, (2) sebelah selatan adalah Desa Takisung Kecamatan Takisung, (3) sebelah timur adalah Desa Ranggang Kecamatan Takisung, dan (4) sebelah barat adalah Laut Jawa. Perbandingan antara jumlah laki-laki dengan jumlah perempuan adalah 935 orang lakilaki berbanding 982 orang perempuan (Direktorat Jenderal Pemberdayaan Masyarakat dan Desa, 2016).

Khalayak sasaran kegiatan ini adalah siswa-siswi SDN Negeri Pagatan Besar, Kecamatan Takisung, Kabupaten Tanah Laut. Para siswa yang mengikuti kegiatan ini dipilih sebanyak 10 orang, masing-masing berasal dari kelas III, IV, V, dan VI sehingga total jumlah siswa yang mengikuti kegiatan adalah sekitar 40 orang. Sebagai tambahan, masing-masing 2 orang guru kelas juga mendampingi siswa mengikuti kegiatan. Dan dua orang perangkat desa termasuk Kepala Desa Pagatan Besar juga diundang sebagai pejabat untuk meresmikan kegiatan ini. Dengan demikian, total peserta yang mengikuti kegiatan ini beserta dengan panitia adalah 50 orang. Pemilihan khalayak sasaran yang berasal dari kalangan siswa sekolah dasar juga sangat tepat karena anak-anak usia sekolah menjadi pintu gerbang perubahan paradigma keberhasilan pengelolaan ekosistem mangrove yang berkelanjutan. Salah satu bekal keterampilan yang dapat dikembangkan melalui kegiatan ini adalah pemanfaatan bahan-bahan alami pada ekosistem mangrove sebagai media belajar dan alat bantu pembelajaran mengelola berbagai peluang bisnis dan konservasi di Pantai Pagatan Besar.

\section{Metode Kegiatan}

Metode kegiatan yang digunakan dalam kegiatan pengabdian masyarakat adalah ceramah, pembahasan pertanyaan, dan latihan pembuatan bahan ajar biologi timpakul dan ekosistem mangrove di lingkungan SDN Pegatan Besar dan Pesisir Pantai Pagatan Besar, Kecamatan Takisung, Kabupaten Tanah Laut .

1. Metode kegiatan yang digunakan dalam kegiatan pengabdian masyarakat ini adalah pemaparan mengenai biologi ikan timpakul dan prospek pemanfaatannya di Pantai Pagatan Besar.

2. Kegiatan kedua adalah pemaparan mengenai ekosistem mangrove dan prospek pemanfaatannya di Pantai Pagatan Besar.

3. Kegiatan ketiga adalah pelatihan pembuatan bahan ajar biologi timpakul dan ekosistem mangrove bagi anak-anak usia sekolah di SDN Pegatan Besar.

4. Kegiatan keempat adalah penilaian produk dari hasil pelatihan bahan ajar biologi timpakul dan ekosistem mangrove bagi anak-anak usia sekolah di SDN Pegatan Besar. 
Anang Kadarsah, Nurul Huda, Krisdianto

5. Kelima adalah kegiatan ekspose atau pemajangan produk pelatihan bahan ajar biologi timpakul dan ekosistem mangrove di halaman SDN dan Balai Desa Pagatan Besar.

\section{Rancangan Evaluasi}

Evaluasi yang digunakan dalam kegiatan ini adalah mengamati perubahan pengetahuan kognitif/nalar siswa-siswa usia sekolah mengenai biologi timpakul dan ekosistem mangrove serta kemampuan psikomotor/ keterampilan membuat bahan ajar untuk tujuan konservasi ekosistem mangrove yang berkelanjutan. Indikator yang digunakan untuk keberhasilan kegiatan ini adalah meningkatnya kemampuan pengetahuan biologi aikan timpakul dan keterampilan membuat bahan ajar untuk menunjang konservasi timpakul dan ekosistem mangrove bagi siswa usia sekolah di Desa Pagatan Besar.

Kriteria yang digunakan adalah sebagai berikut :

1. Bernilai A (sangat memuaskan) jika $75 \%$ dari seluruh peserta kegiatan berhasil mendapat nilai evaluasi sama dengan atau lebih dari 80.

2. Bernilai B (memuaskan) jika $75 \%$ dari seluruh peserta kegiatan berhasil mendapat nilai evaluasi antara 70 sampai dengan 80 .

3. Bernilai $\mathrm{C}$ (cukup memuaskan) jika $75 \%$ dari seluruh peserta kegiatan berhasil mendapat nilai evaluasi antara 60 sampai dengan 70 .

\section{HASIL DAN PEMBAHASAN}

\section{Pendahuluan}

Kegiatan pembuatan alat bantu ajar biologi timpakul dan ekosistem mangrove bagi anak sekolah dasar di SDN Pegatan Besar, Desa Pagatan Besar, Kabupaten Tanah Laut dilaksanakan pada hari Sabtu tanggal 27 Oktober 2018. Sebelum masuk ke dalam ruangan kelas terlebih dahulu diadakan pertemuan dengan kepala sekolah SDN Pegatan Besar bapak Iberani, S.Pd. beserta guru-guru kelas diantaranya Ibu Mila sebagai Wali Guru Kelas VI. Perkenalan dan ramah tamah dengan staf, guru dan kepala sekolah SDN Pegatan Besar dilangsungkan di ruangan tamu dengan suasana kekeluargaan.

\section{Presentasi Bahan Ajar Timpakul dan Ekosistem Mangrove}

Kegiatan selanjutnya adalah penyampaian bahan ajar dengan tema pengenalan ekosistem mangrove, dan penghuninya (timpakul dan moluska) menggunakan media presentasi power point (Gambar 2). Dalam paparannya disebutkan bahwa mangrove diartikan sebagai tumbuhan berkayu maupun semak belukar yang menempati habitat antara daratan dengan lautan dan secara periodik tergenangi air pasang (Hogart, 2007). Mangrove merupakan ekosistem yang hidupnya terbatas di daerah tropis (Cannicci et al., 2008), terdiri dari rangkaian vegetasi yang hampir seragam dan spesifik (Feller \& Sitnik, 1996). Mangrove umumnya ditemukan pada pesisir pantai Pasifik, termasuk Indonesia, Melanesia, dan Mikronesia (Kitamura, Anwar, Chaniago, \& Baba, 1997), kemudian meluas sampai ke pantai timur Afrika (Duke, 2006). Adapun dari segi iklim, vegetasi ini tumbuh baik pada suhu $19{ }^{\circ} \mathrm{C}$ sampai dengan $40{ }^{\circ} \mathrm{C}$ (Irwanto, 2007). 


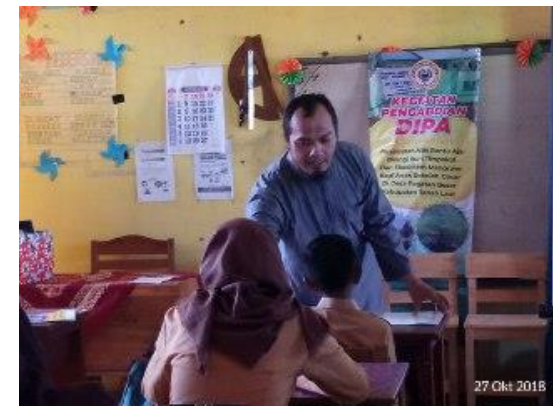

Gambar 2. Presentasi bahan ajar bagi anak-anak sekolah dasar di SDN Pegatan Besar dengan tema pengenalan ekosistem mangrove, dan penghuninya (timpakul dan moluska).

Pada ekosistem mangrove, hanya dapat ditemukan sekitar 100 jenis tumbuhan, jauh lebih sedikit dibandingkan dengan ribuan jenis yang tumbuh pada ekosistem terestrial (Hogart, 2007). Jenis-jenisnya antara lain : (1) Famili Rhizophoraceae, terdiri dari : Bakau (Rhizophora mucronata), Tanjang (Bruguiera Sp.), dan Bakau kuning (Ceriops Sp.). (2) Famili Sonneratiaceae, contohnya : Perapat atau Gogem (Sonneratia Sp.). (3) Famili Avicenniaceae, seperti : Api-api (Avicennia Sp.), dan (4) Famili Meliaceae seperti : Nipah (Nypa fructicans) (Fatma, 2015). Selain itu dijumpai perdu yakni Jeruju (Acanthus Sp.).

Ikan timpakul merupakan salah satu jenis fauna yang dapat ditemukan pada ekosistem mangrove, ikan ikan mampu beradaptasi yang baik pada kondisi berlumpur dan memungkinkan bergerak efektif di darat maupun di air. Timpakul juga memiliki kemampuan untuk bernafas melalui kulit dan lapisan mulut (mukosa) dan tenggorokan (faring) dengan cara menghirup udara melalui kulit, ikan ini biasanya menggali lubang pada sedimen untuk menghindari predator laut selama pasang ketika sarangnya (Polgar, 2008). Beberapa jenis ikan timpakul yang biasa ditemukan hidup pada ekosistem mangrove di Kalimantan Selatan, antara lain : Periophthalmodon schlosseri, Boleophthalmus boddarti, Boleophthalmus pectinirostris, dan Priophthalmus novemradiatus.

Pada ekosistem mangrove, moluska dapat ditemukan hidup di permukaan dan di dalam substrat serta menempel pada pohon mangrove, baik jenis gastropoda dan bivalvia (Hartono \& Agussalim, 2013). Jenis-jenis Moluska yang biasa ditemukan pada ekosistem mangrove antara lain : Cassidula aurisfelis, Littotaria scabra, Pugilina cochlidium, Chicoreus capucinus, Telescopium telescopium dan Polymesoda erosa.

\section{Demo Penggunaan Poster Sebagai Bahan Ajar}

Acara selanjutnya adalah pengayaan materi bahan ajar ilmu pengetahuan alam di Sekolah Dasar dengan menggunakan bantuan poster. Dalam hal ini penggunaan poster sebagai alat bantu ajar memiliki keunggulan antara lain : (1) sebagai penggerak perhatian; (2) sebagai petunjuk; (3) sebagai peringatan, pengalaman kreatif; (4) untuk kampanye (https://brainly.co.id/tugas/5222425). Dalam pembuatan poster untuk bahan pembelajaran dibuat menjadi tiga macam yakni poster tentang tumbuhan mangrove dan 
ikan timpakul (Gambar 3.) dan poster tentang moluska (Gambar 4.) pada ekosistem mangrove.

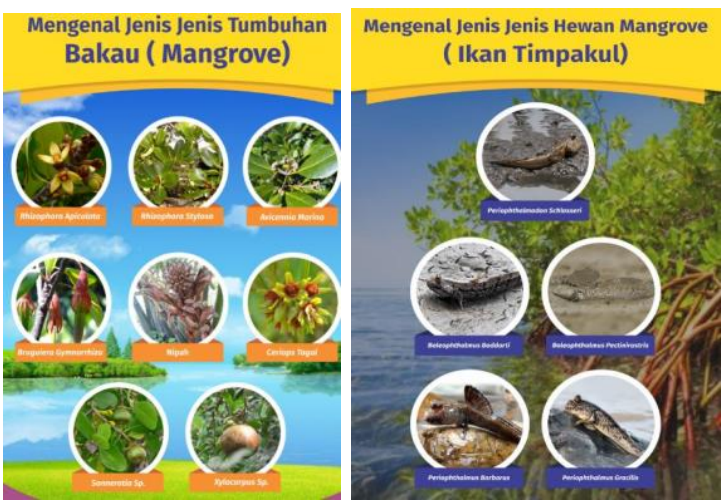

Gambar 3. Poster tentang jenis-jenis tumbuhan dan ikan timpakul yang dapat ditemukan pada ekosistem mangrove.

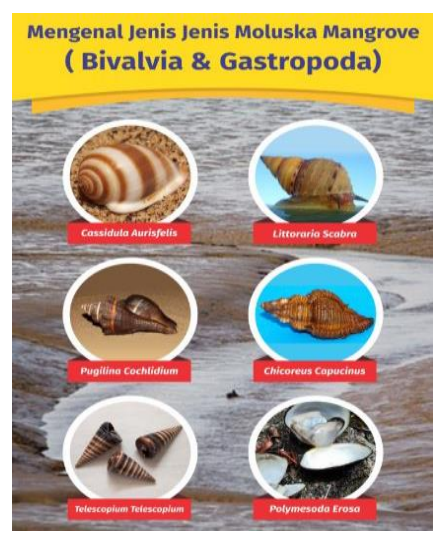

Gambar 5. Poster tentang jenis-jenis moluska (bivalvia dan gastropoda) yang dapat ditemukan pada ekosistem mangrove.

\section{Pemutaran Video Bahan Ajar}

Penggunaan media video sebagai alat bantu ajar diperkirakan dapat meningkatkan efektivitas proses pembelajaran sehingga pencapaian tujuan belajar secara maksimal. Diketahui sekitar $75 \%$ pengetahuan diperoleh melalui penglihatan, $13 \%$ pendengaran, $6 \%$ sentuhan dan $6 \%$ penciuman. Video juga dapat memberikan gambaran yang realistis terhadap obyek materi pembelajaran dan mampu menjelaskan konten dengan lebih nyata namun memiliki kelemahan yakni tidak interaktif (https://slideplayer.info/slide/3627005/).

Di era zaman now, kita dimudahkan dengan banyaknya situs online bisa dimanfaatkan sebagai media pembelajaran. Misalnya situs https://www.zenius.net/. Situs ini menyediakan berbagai materi pembelajaran mulai dari tingkat SD hingga SMA, sehingga guru bisa memanfaatkannya sebagai sumber belajar dan memanfaatkan situs belajar online ini untuk meng-eksplorasi kemampuan siswa melalui latihan soal secara online. Dalam kegiatan pengabdian ini penggunaan video sebagai media pembelajaran juga dikenalkan kepada siswa kelas VI di SDN Pegatan Besar (Gambar 6.). 


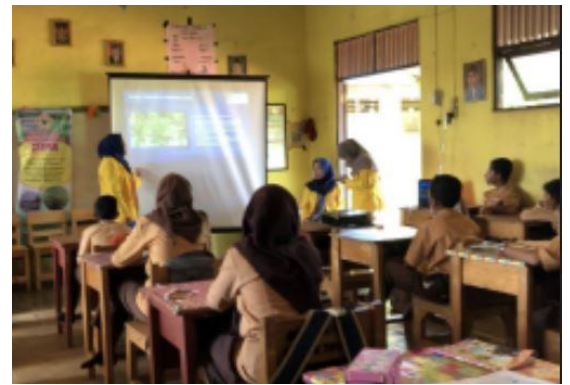

Gambar 6. Penyampaian bahan ajar ekosistem mangrove dengan video pembelajaran di SDN Pegatan Besar

\section{Menggambar Ekosistem Mangrove dan Ikan Timpakul}

Kegiatan pembelajaran selanjutnya adalah menggambar ekosistem mangrove dan timpakul (Gambar 7). Menggambar bukan hanya sekadar aktivitas yang menyenangkan saja bagi anak, tapi berperan penting dalam tumbuh kembangnya di masa mendatang. Manfaat menggambar bagi perkembangan anak sangatlah banyak, salah satunya adalah mengasah kemampuan seni serta meningkatkan sisi kreativitasnya. Menggambar memiliki berbagai manfaat bagi perkembangan fisik, motorik dan kognitif anak. Manfaat menggambar yang penting antara lain : melatih kecerdasan motorik, menuntut anak untuk berpikir ketika berimajinasi serta meningkatkan ingatan, salah satu media terbaik untuk menyampaikan pesan, menyalurkan emosi, atau hal-hal lain yang tidak dapat disampaikan secara lisan serta akan melatih kesabaran anak (Jessica, 2018).

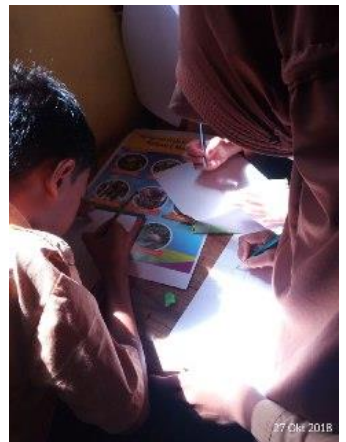

Gambar 7. Kegiatan menggambar ekosistem mangrove dan timpakul oleh anak-anak kelas VI SDN Pegatan Besar.

Berikut ini adalah salahsatu tampilan hasil karya menggambar ekosistem mangrove dan timpakul oleh anak-anak kelas VI SDN Pegatan Besar (Gambar 8.). Tampak bahwa sebagian besar anak-anak kelas VI SDN Pegatan Besar antusias dengan kondisi lingkungannya yakni banyak dijumpai ekosistem mangrove dan juga sudah mengenal adanya ikan timpakul. 


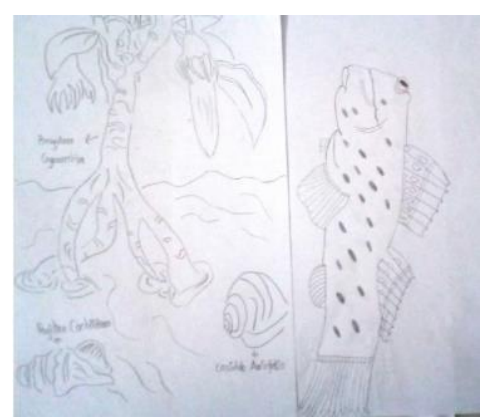

Gambar 8. Contoh hasil kegiatan menggambar ekosistem mangrove dan timpakul oleh anak-anak kelas VI SDN Pegatan Besar

\section{Evaluasi Kegiatan Pengabdian dan Kuesioner Kemampuan}

Acara kegiatan pengabdian Pembuatan Alat Bantu Ajar Biologi Timpakul Dan Ekosistem Mangrove Bagi Anak Sekolah Dasar Di Desa Pagatan Besar Kabupaten Tanah Laut, yang diselenggarakan oleh tim pengabdian Program Studi Biologi FMIPA Universitas Lambung Mangkurat Alhamdulillah selesai dilaksanakan pada tanggal 27 Oktober 2018. Kegiatan ini terselenggara atas rahmat karunia dari Allah Subhanahuwata'ala, kemudian karena kemudahan dan kerjasama kepala sekolah, guru, dan siswa-siswa di SDN Pegatan Besar, Kabupaten Tanah Laut. Sebagai tanda syukur dan terima kasih atas kedatangan tim pengabdian Program Studi Biologi FMIPA Universitas Lambung Mangkurat, sebagai tuan rumah Kepala Sekolah SDN Pegatan Besar, sengaja mengajak tim pengabdian untuk makan siang bersama. Bertempat di aula atau ruang tamu sekolah kami dijamu dengan hidangan ikan bakar dan lalapan serta minuman teh manis hangat Alhamdulillah nikmat dari Allah Subhanahu wata'ala dan ucapan terima kasih tentunya disampaikan kepada kepala sekolah, guru, dan siswa-siswa di SDN Pegatan Besar.

Dalam rangka evaluasi kegiatan pengabdian Pembuatan Alat Bantu Ajar Biologi Timpakul Dan Ekosistem Mangrove Bagi Anak Sekolah Dasar Di Desa Pagatan Besar Kabupaten Tanah Laut, maka tim pengabdian melaksanakan survey kepada anak-anak sekolah di SDN Pegatan Besar. Kegiatan ini untuk mengetahui sejauh mana peningkatan pengetahuan anak-anak sekolah dalam mengenal ekosistem mangrove dan timpakul serta mengenal pencipta-Nya. Juga mengetahui manfaat yang diperoleh dari penggunaan alat bantu ajar bagi perkembangan psikomotorik merek. Beberapa pertanyaanpertanyaan yang diajukan kepada siswa-siswa kelas VI di SDN Pegatan Besar antara lain pengetahuan jenis-jenis tumbuhan, pengenalan ikan timpakul dan pengetahuan mengenai moluska pada ekosistem mangrove. .

Hasil kuesioner menunjukkan sebanyak 40 peserta yakni siswa kelas 6 SDN Pegatan Besar berpartisipasi mengikuti kegiatan ini. Data kuesioner yang diperoleh berdasarkan tahun kelahirannya, siswa yang lahir pada tahun 2006 lebih banyak jumlahnya (63\%) dibandingkan dengan siswa yang lahir pada tahun 2007 (23\%), tahun 2005 (12\%), dan tahun 2004 (2\%) (Gambar 10.) Dengan demikian diketahui bahwa siswa kelas VI di SDN Pegatan besar kebanyakan berusia 12 tahun. Kondisi ini ideal bagi anak untuk meneruskan pendidikan dasar ke jenjang yang lebih tinggi. 


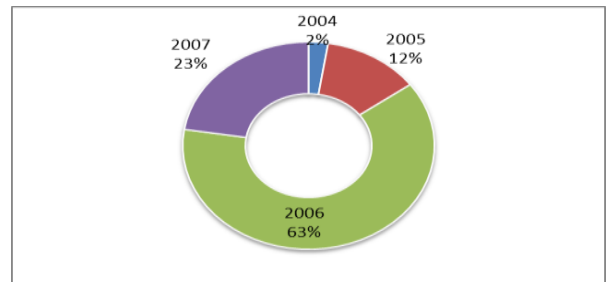

Gambar 10. Perbandingan jumlah peserta pengabdian Pembuatan Alat Bantu Ajar Biologi Timpakul Dan Ekosistem Mangrove Bagi Anak Sekolah Dasar berdasarkan tahun kelahiran di SDN Pegatan Besar.

Pendapat siswa kelas VI SDN Pegatan Besar mengenai ekosistem mangrove dan timpakul pada rangkaian kegiatan pengabdian pembuatan alat bantu ajar biologi timpakul dan ekosistem mangrove ditampilkan pada Gambar 11 di bawah ini.
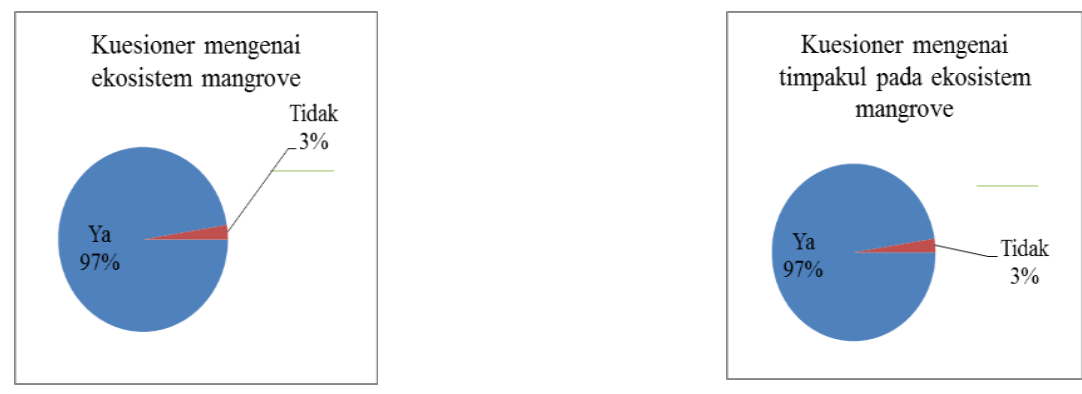

Gambar 11. Pendapat siswa kelas VI SDN Pegatan Besar mengenai ekosistem mangrove dan timpakul pada rangkaian kegiatan pengabdian pembuatan alat bantu ajar biologi timpakul dan ekosistem mangrove

Sedangkan pertanyaan kuesioner yang diajukan kepada peserta mengenai ekosistem mangrove diperoleh jawaban sebagai berikut : sebanyak 97\% peserta menjawab mengetahuinya dan sisanya (3\%) tidak mengetahui. Demikian pula untuk kuesioner mengenai timpakul pada ekosistem mangrove sebanyak $97 \%$ peserta menjawab mengetahuinya dan sisanya (3\%) tidak mengetahuinya.

\section{Simpulan}

\section{PENUTUP}

1. Kegiatan pengabdian pembuatan alat bantu ajar biologi timpakul dan ekosistem mangrove Alhamdulillah berhasil dilaksanakan. Sebanyak lima kegiatan penting pengabdian yang berhasil disampaikan antara lain : perkenalan tim pengabdian, presentasi ekosistem mangrove dan timpakul, pemutaran video bahan ajar, pembuatan gambar mangrove dan timpakul, dan pengisian kuesioner

2. Hasil evaluasi dan kuesioner dari sebanyak 40 siswa kelas VI SDN Pegatan Besar yang mengisi lembar evaluasi sebagian besar menyatakan tahu tentang ekosistem mangrove dan timpakul (97\%). Namun hanya sebagian kecil $(2,5 \%)$ responden yang menjawab dengan lengkap bahwa untuk pelestarian mangrove dan timpakul 
Anang Kadarsah, Nurul Huda, Krisdianto

kita harus menjaga dan melestarikan mangrove dan harus membuang sampah ke tempat sampah.

\section{Saran}

Saran untuk kegiatan selanjutnya adalah perlu diadakan kegiatan dalam skala lebih besar yakni pelatihan pengelolaan kreativitas dari ekosistem mangrove sebagai alat bantu pembelajaran bagi seluruh siswa di wilayah kecamatan Takisung, Kabupaten Tanah Laut.

\section{DAFTAR PUSTAKA}

Anonim. 2017. Tempat Wisata Mangrove di Pagatan Besar mulai Ramai Pengunjung. Alamat web : http://www.pelpost.com/Ls/Br/?s=5j6gPpUA. diakses tanggal 23 Mei 2018.

Cannicci, S., Burrows, D., Fratini, S., Smith, T. J., Offenberg, J., \& Dahdouh-Guebas, F. (2008). Faunal Impact on Vegetation Structure and Ecosystem Function in Mangrove Forests: A Review. Aquatic Botany, 89, 186-200.

Duke, N. C. (2006). Rhizophora apiculata, R. mucronata, R. stylosa, R. $\times$ annamalai, R. $\times$ lamarckii (Indo-West Pacific stilt mangroves), ver. 2.1. In: Elevitch, C.R. (ed.). Species Profiles for Pacific Island Agroforestry, Hawai'i. Retrieved September 2, 2018, from http://www.traditionaltree.org

Fatma, D. (2015). 4 Jenis Hutan Mangrove yang Ada di Dunia. Retrieved from https://ilmugeografi.com/ilmu-bumi/hutan/jenis-hutan-mangrove

Feller, I. C., \& Sitnik, M. (1996). Mangrove Ecology: A Manual for a Field Course A Field Manual Focused on the Biocomplexity on Mangrove Ecosystems. Washington. DC: Smithsonian Institution.

Hartono, \& Agussalim, A. (2013). Komposisi dan Kelimpahan Moluska (Gastropoda dan Bivalvia) di Ekosistem Mangrove Muara Sungai Musi KabupatenBanyuasin Provinsi Sumatera Selatan. Maspari Journal, Volume 5. ISSN: 2087-0558), 6 15 .

Hogart, P. (2007). The Biology of Mangroves and Seagrasses. New York : Oxford University Press.

Hafizianor. 2009. Interaksi, Persepsi Dan Sikap Masyarakat Terhadap Kawasan Suaka Margasatwa (Studi Kasus di Kawasan Suaka Margasatwa Pelaihari Kabupaten Tanah Laut). Jurnal Hutan Tropis Borneo No. 26, Edisi Juni 2009. Alamat web : http://download.portalgaruda.org/article.php?article $=96182 \& v a l=5070$.

Irwanto. (2007). Analisis Vegetasi Untuk Pengelolaan Kawasan Hutan Lindung Pulau Marsegu, Kabupaten Seram Bagian Barat, Provinsi Maluku. Yogyakarta : Laporan Akhir Tesis Pascasarjana, UGM.

Jessica. (2018). 7 Manfaat Menggambar bagi Perkembangan Anak. Retrieved from https://www.educenter.id/7-manfaat-menggambar-bagi-perkembangan-anak-2/ 
Kadarsah, A., dan Krisdianto. 2017. Kajian Aplikasi Coarse Filter Dalam Upaya Konservasi Moluska (Bivalvia dan Gastropoda) di Ekosistem Mangrove, Kecamatan Takisung, Kabupaten Tanah Laut). Laporan Penelitian Pembinaan Kapasitas. DIPA Universitas Lambung Mangkurat. (Tidak dipublikasikan).

Kitamura, S., Anwar, C., Chaniago, A., \& Baba, S. (1997). Handbook of Mangroves in Indonesia. Bali and Lombok. The Development of Sustainable Mangrove Management Project. Denpasar: Forestry Ministry of Indonesia and Japan International Cooperation Agency.

Nielsen, D.M. 2008. Mengelola Kelas untuk Guru TK diterjemahkan oleh Febrianti Ika Dewi. Jakarta: Index.

Sujiono. 2007. Metode Pengembangan Fisik. Jakarta: Universitas Terbuka 